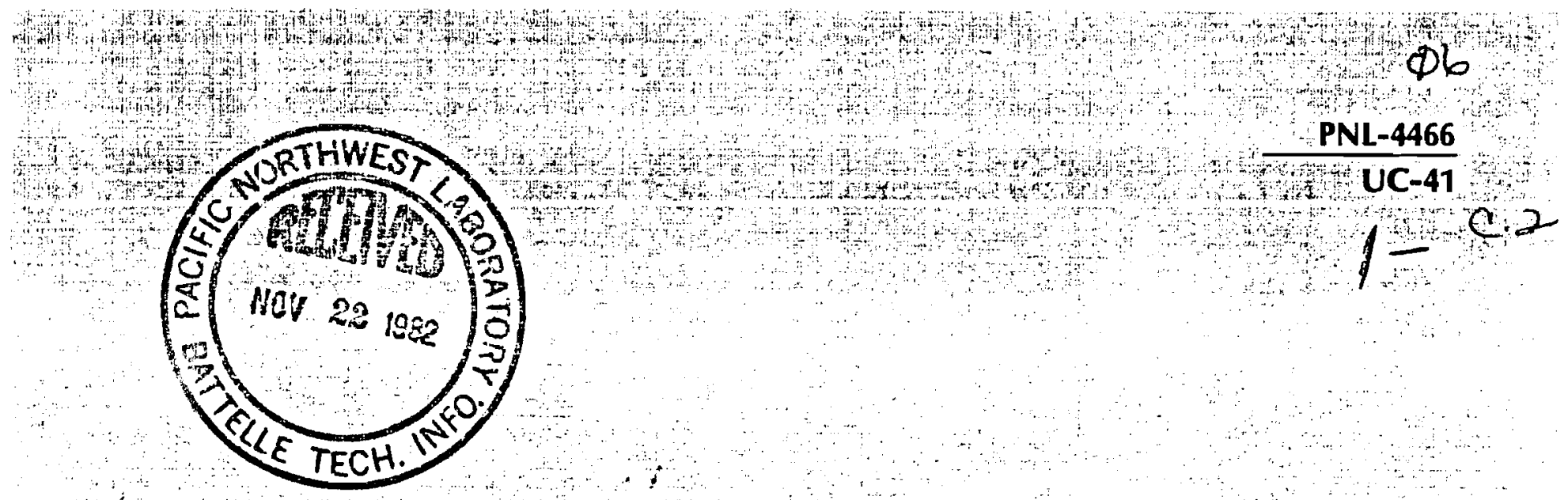

\title{
Uranium and Other Heavy Metals in Soil and Vegetation from the Hanford Environs
}

\author{
K. R. Price \\ R. R. Kinnison
}

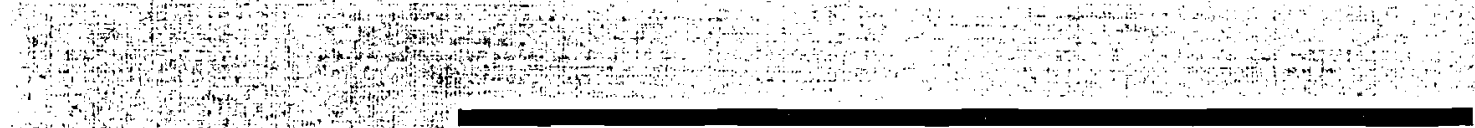

November 1982

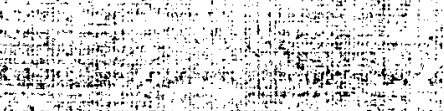

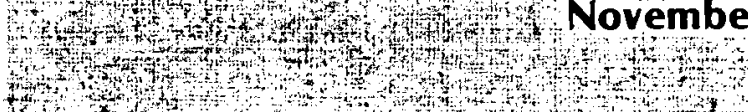

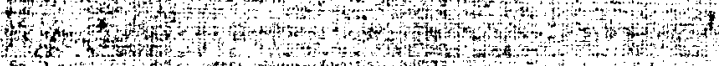

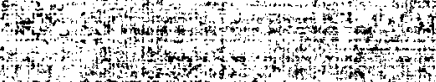

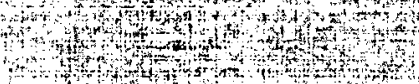

Prepared for the U.S. Department of Energy under Contract DE-AC06-76RLO 1830

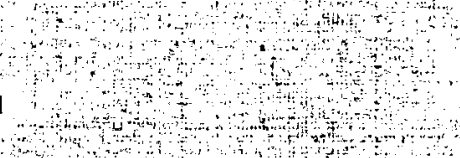

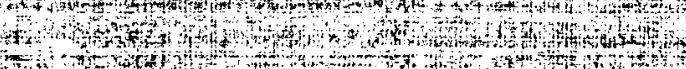

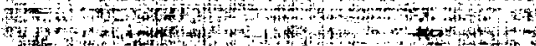

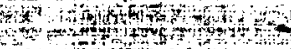

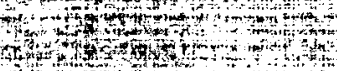
$+4$

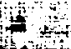
Pacific Northwest Laboratory
Operated for the U.S. Department of Energy
by Battelle Memorial Institute

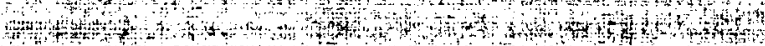

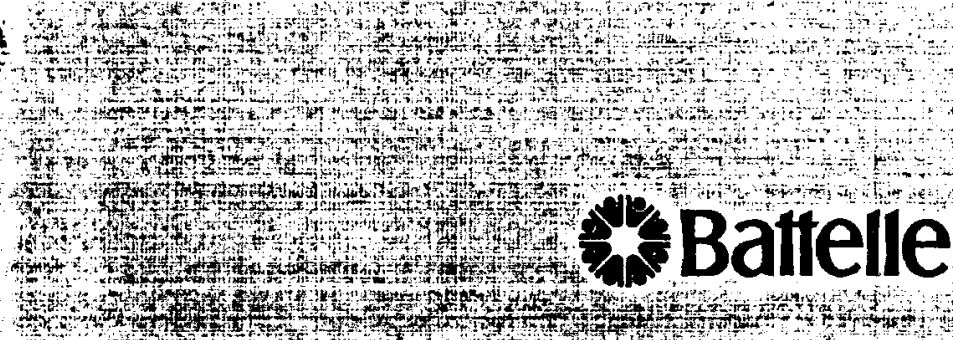

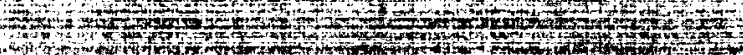
IM

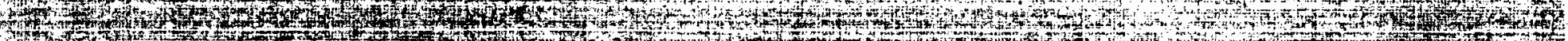

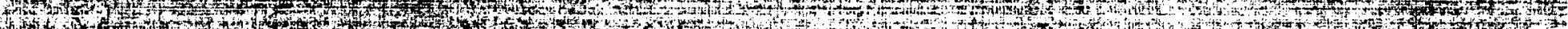

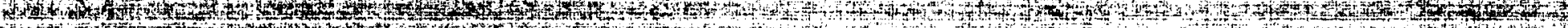

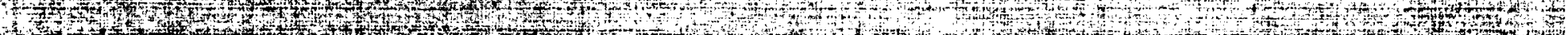

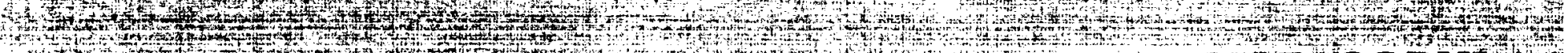

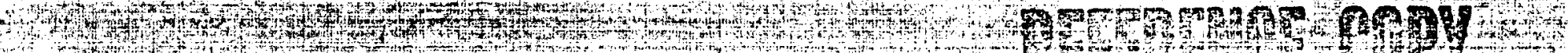




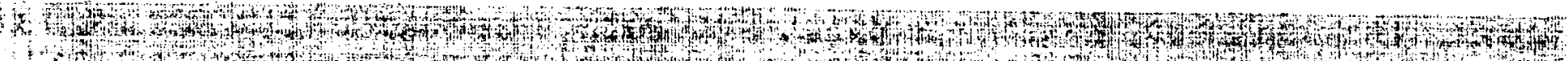

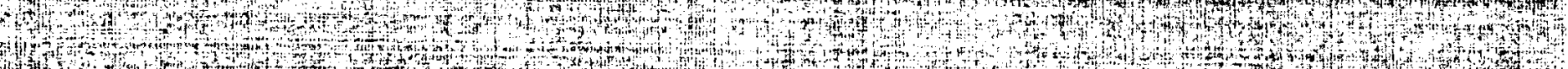

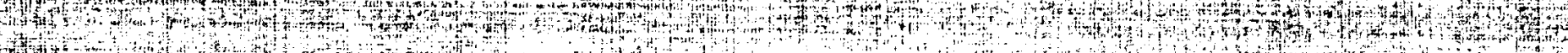

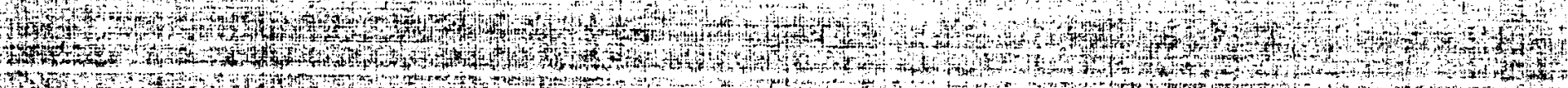

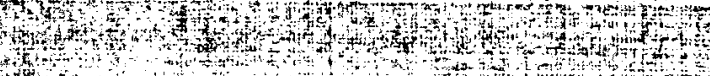

This report was prepared as an account of work sponsored by an agency of the United States Government. Neither the United States Government nor any agency thereof, nor any of their employees, makes any warranty, express or implied, or assumes any legal liability or responsibility for the accuracy, completeness, or usefulness of any information, apparatus, product, or process disclosed, or represents that its use would not infringe privately owned rights. Reference herein to any specific commercial product, process, or service by trade name, trademark, manufacturer, or otherwise, does not necessarily constitute or imply its endorsement, recommendation, or favoring by the United States Government or any agency thereof. The views and opinions of authors expressed herein do not necessarily state or reflect those of the United States Government or any agency thereof.

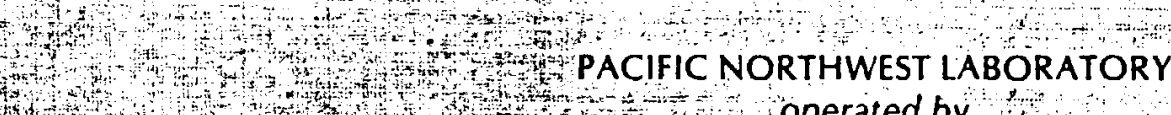

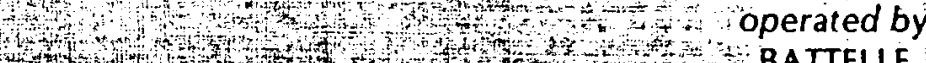

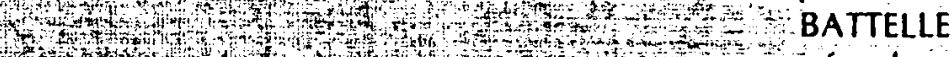

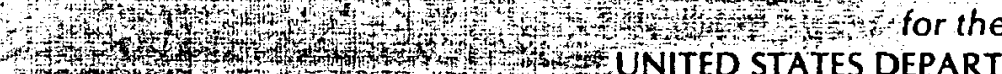

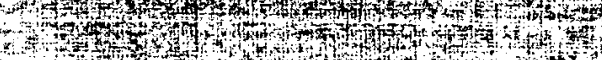

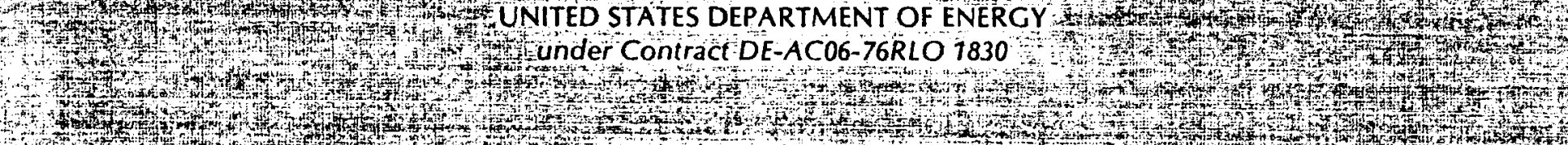

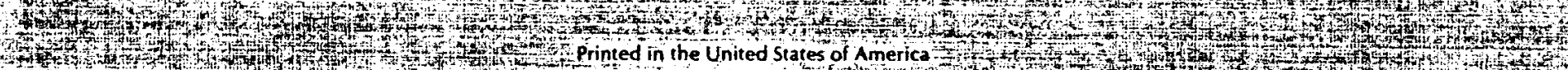

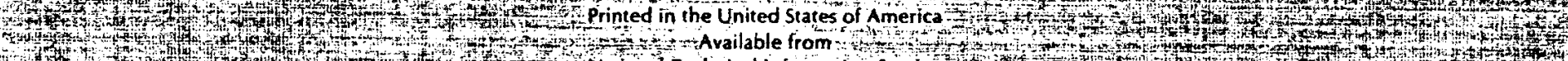

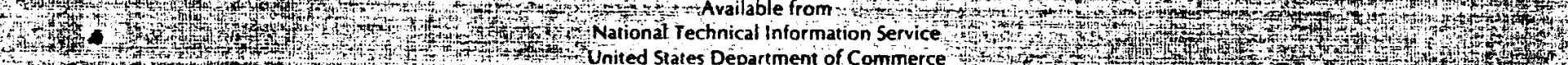
1
4

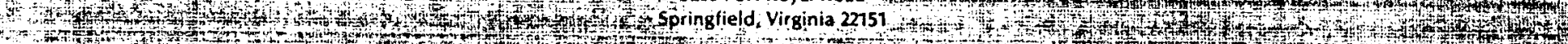

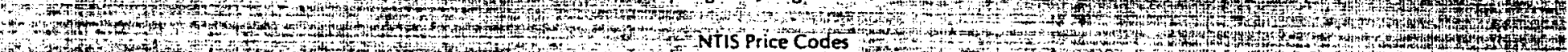

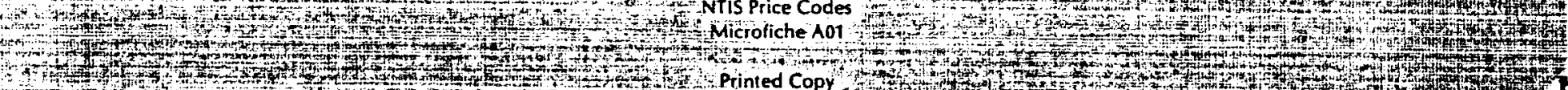

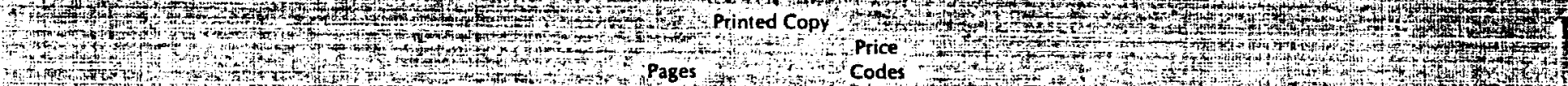

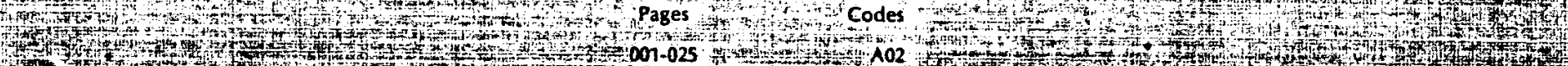

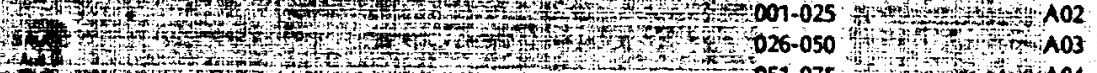

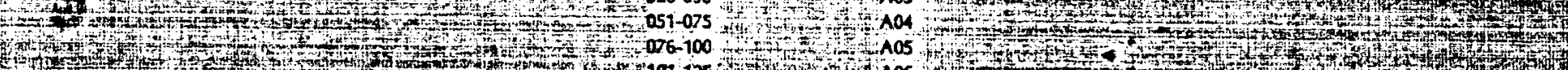

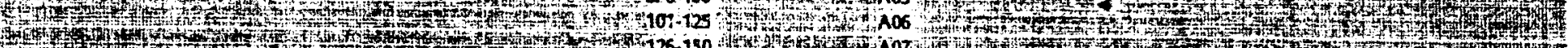

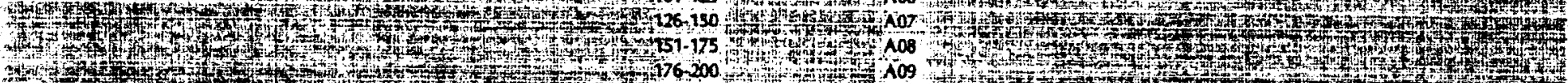
Ny Hof

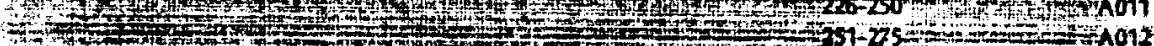

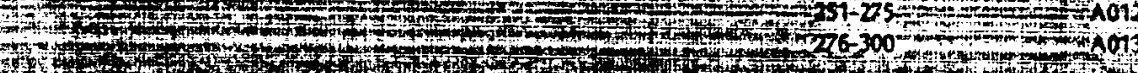

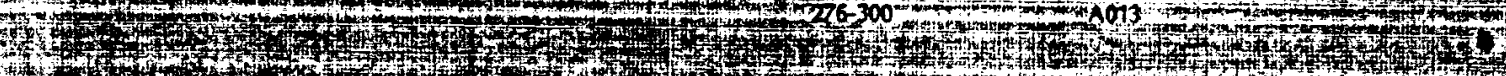

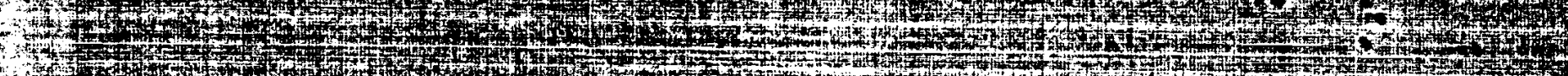
1 1.74 If

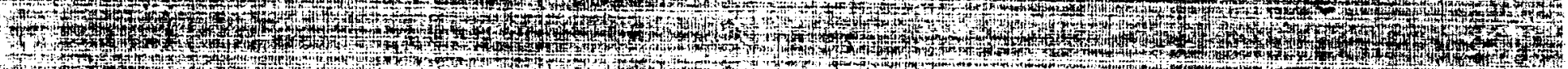

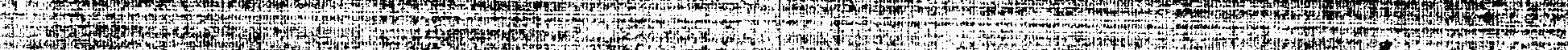


URANIUM AND OTHER HEAVY METALS IN SOIL AND VEGETATION FROM THE HANF ORD ENVIRONS

K. R. Price

R. R. Kinnison

November 1982

Prepared for the U.S. Department of Energy under Contract DE-AC06-76RLO 1830

Pacific Northwest Laboratory

Richland, Washington 99352 


\section{SIMMMARY}

Strong winds that could transport contaminated dust and other materials offsite from the Hanford 300 Area typically blow from the west or southwest. Samples were collected from an offsite study area located across the Columbia River and downwind from the 300 Area to estimate the concentrations of uranium and other heavy metals in soils and vegetation. Results were compared to similar measurements collected at control sites located both on and off the Hanford Site. These comparisons were used to test hypotheses that ur anium and other heavy metals had been transported offsite by wind-blown dust or other materials.

The conclusion from this study was that operations at the 300 Area have not resulted in a detectable impact on the offsite environs across the river. The concentration of uranium in soil samples from the study area was statistically greater than comparable samples from control sites, but there was no evidence that the uranium in the study-area samples was other than naturally occurring. There was no statistical difference in the concentration of lead, silver, zinc or copper in soil samples from the study area as compared to the control sites. No statistically significant differences in uran ium or other heavy metals were noted among vegetation samples from the various sampling sites. 


\section{CONTENTS}

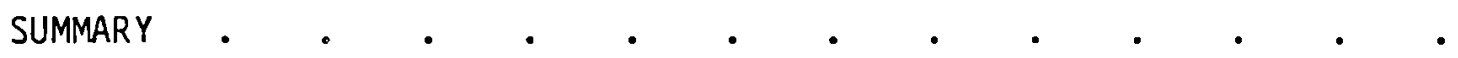

INTRODUCTION

300 AREA . . . . . . . . . . . . . . . . . . 1

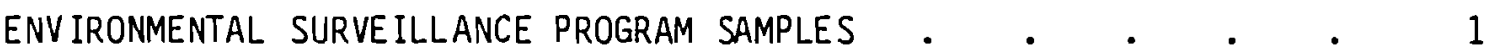

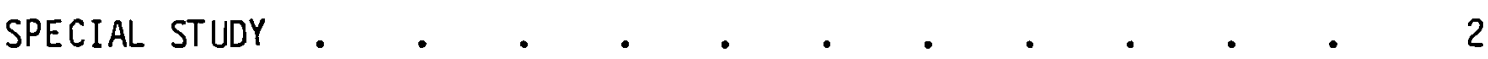

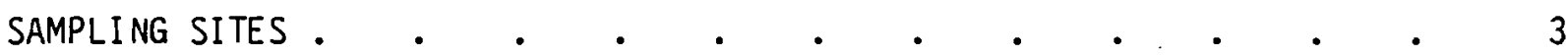

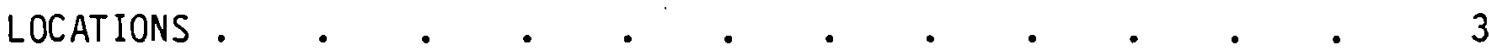

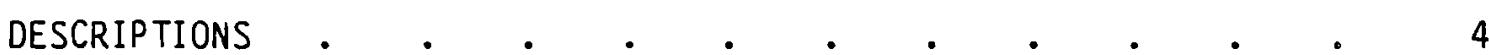

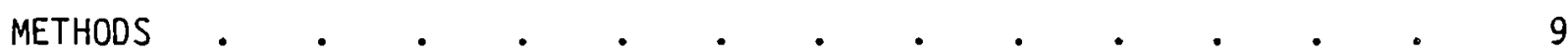

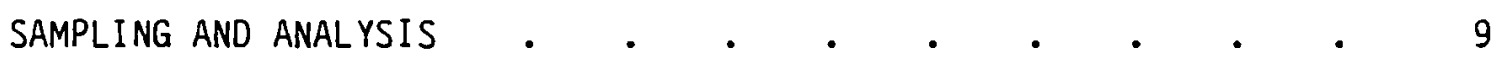

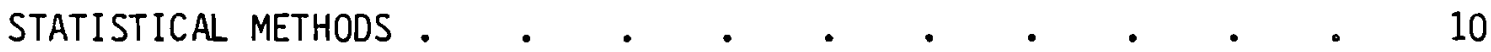

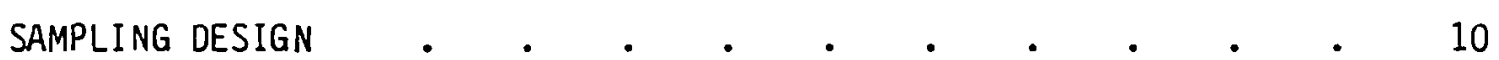

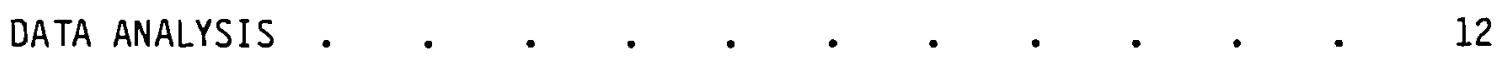

RESULTS AND DISCUSSION

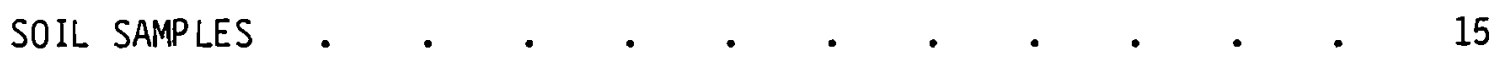

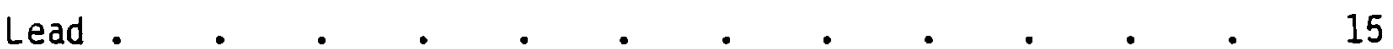

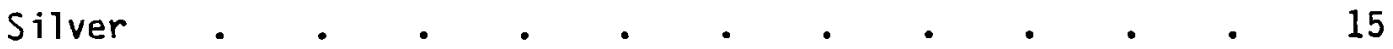

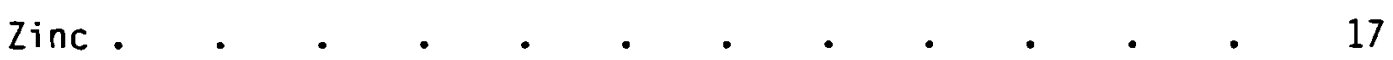

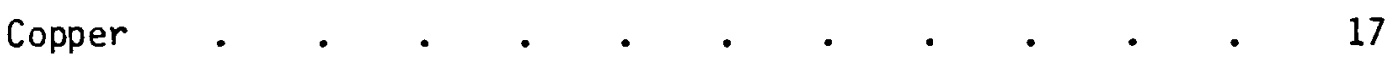

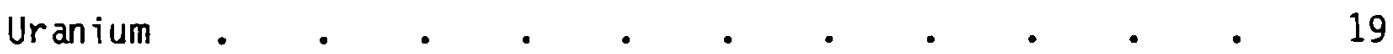

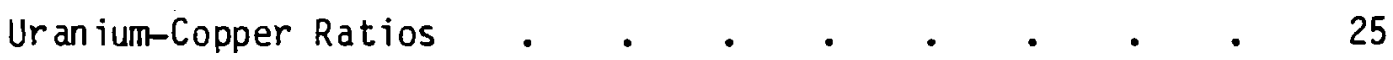

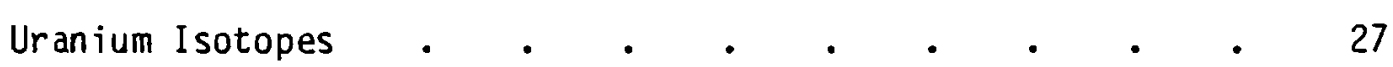

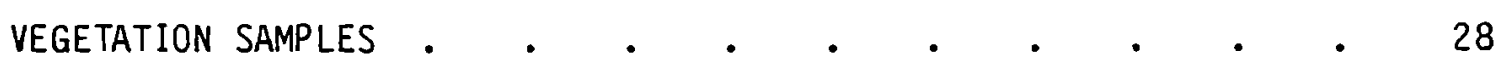




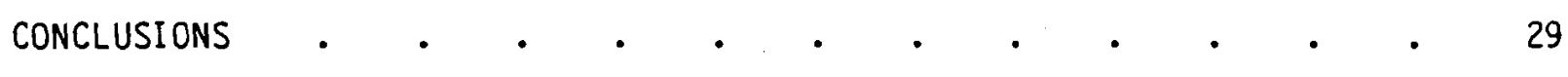

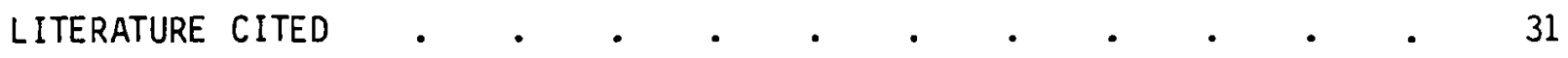




\section{FIGURES}

1 Sampling Locations in the Environs of the Hanford Site and a Surface

2 An Aerial Photograph Looking Southeast Toward the Study Area Located on Bluffs along the Columbia River . . . . . . .

3 Probability Plots of Soil Uranium Concentrations for the Historical Data Base and for the Study Area . . . . . . 19

4 Graphic Representation of the Spatial Pattern of Uranium Concentrations in Field Composite Samples Collected from the Study Area

5 Cross Plot of Uranium and Uranium Quality Control Data for Soil Samples

6 Cross Plot of Uranium Concentration and the Ratio of Uranium Error to Uranium Concentration.

TABLES

1 Locations and Characteristics of the Sampling Sites . $\quad$ • 6

2 Soil and Vegetation Samples Collected at Each Sampling Site . . 11

3 Mean, Standard Deviation, and Range of Heavy Metal Analyses

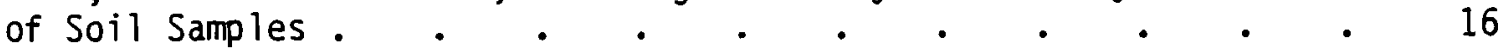

4 Uranium in Soil Samples from the Environs of the Hanford Site . 20

5 One-Way Analysis of Variance for Differences in Soil Uranium Concentrations Between Sampling Sites . $\quad$. $\quad . \quad$. $\quad 21$

6 Average Atom Percent of Uranium Isotopes in Soil Samples . . 27

7 Mean, Median and Range of Uranium and Heavy Metals in Vegetation Samples 


\section{INTRODUCTION}

Several methods have been used to control the release of effluents produced at the Hanford Site since facility startup in 1944. Gaseous effluents have been treated by filtration or other control measures to reduce the amounts of materials released to the atmosphere. Most liquid effluent streams, except reactor cooling water, have been retained onsite through the use of underground structures (e.g., cribs) or surface structures such as ponds. The principal method of liquid effluent control in the 300 Area involved the use of special waste disposal ponds.

\section{AREA}

The use of 300-Area facilities has involved research and development activities and reactor fuel fabrication. Building air exhaust was filtered, but considerable amounts of heavy metals, including uranium, were released to process waste ponds from 1944 to 1975. Improvements in eff luent cleanup were effected in 1975, and liquid wastes were directed to newly constructed leaching trenches. Use of the original ponds was discontinued. The ponds were subsequently covered with fly ash and soil and gravel from the dikes and sidewalls to prevent strong winds from dispersing materials accumulated on the bottoms of the ponds.

\section{ENVIRONMENTAL SURVEILLANCE PROGRAM SAMPLES}

In 1975 two new soil and vegetation sampling sites were added to the routine Hanford Environmental Surveillance Program in preparation for the startup of Fast Flux Test Facility (FFTF) operations. The sites were located offsite near the eastern shore of the Columbia River and downwind in the predominant wind direction from FFTF. The sampling locations also were downwind in the strong wind direction from the 300 Area. Most results from soil samples and some results from vegetation samples collected from 1978 through 1981 seemed to show higher than expected concentrations of uranium. 
SPECIAL STUDY

The purpose of this study (a) was to estimate the concentrations of uranium and other heavy metals in soil and vegetation samples collected across the Columbia River from the 300 Area. Analytical results were compared to those for samples collected from control sites located both onsite and offsite. The onsite control sites were located in areas remote from facilities handling uranium or heavy metals. Results were used to test the hypotheses that uranium or heavy metals had accumulated in the environment across the river from the 300 Area due to the transport of contaminated dust or other materiais by strong winds.

(a) This work was conducted by Pacific Northwest Laboratory under the Hanford Environmental Surveillance Program through Service Assessment funding provided by The Safety and Environmental Protection Division of the Richland Office of the U.S. Department of Energy (DOE-RL). 


\section{SAMPLING SITES}

Samples were collected from a study area hypothesized to be impacted by the wind transport of ur anium and other heavy metals from the 300 Area. Other sites were chosen to represent background or control sites presumed to be unaffected by operations at Hanford. A privately owned and operated uranium fuel fabrication facility (Exxon) is located upwind from the 300 Area. Samples were collected on Federal land across a road from Exxon to assure that the facility was not an external source of uranium effluents.

\section{LOCATIONS}

Samples of soil and native vegetation were collected from the study area and four control sites. Another site was sampled near the Exxon Nuclear Company, Inc. facility on Horn Rapids Road. Figure 1 is a map of the region showing the locations of the study area, control sites, and the Exxon site with an inset showing the location of individual sampling sites within the study area. Figure 2 is an aerial photograph of the study area. The 300 Area is located adjacent to the Columbia River just outside of the picture on the right. Groups of samples were collected at about $0.8-\mathrm{km}$ intervals along a road near the river shoreline as noted by the arrows in Figure 2. At each $0.8-\mathrm{km}$ interval, samples were collected near the road and also at elevations of about 40 and $80 \mathrm{~m}$ above the road on the bluffs. The height of the bluffs above the road is 120 to $130 \mathrm{~m}$. The road is about $10 \mathrm{~m}$ above the river.

The most southern sampling site for the study area was located adjacent to the 300 Area on the Franklin County side (eastern shore) of the Columbia River. Individual sampling sites extended north at $0.8-\mathrm{km}$ intervals for $\sim 5.6 \mathrm{~km}$. Thus individual sampling sites $r$ anged from $\sim 1$ to $6 \mathrm{~km}$ from the 300 Area. Table 1 shows the distance and direction of all sampling sites from the 300 Area along with other characteristics. 


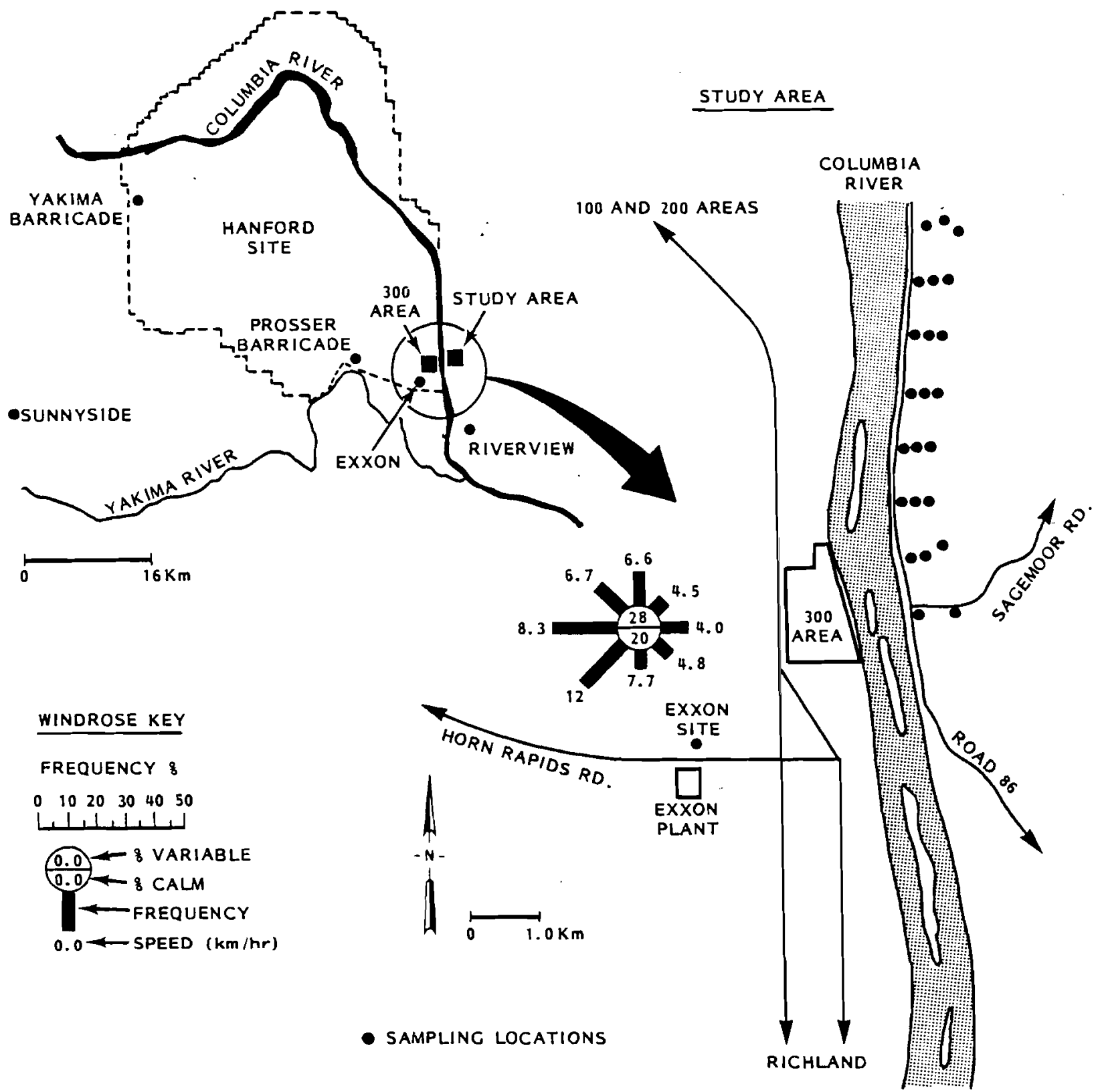

FIGURE 1. Sampling Locations in the Environs of the $H$ anford Site and $A$ Surface Wind Rose for the 300 Area

\section{DESCRIPTIONS}

The study-area sampling sites were located on bluffs along the eastern shore of the Columbia River. The bluffs were strongly eroded resulting in steep hill and gully topography. Individual study sites were confined to the 
TABLE 1. Locations and Characteristics of the Sampling Sites

\begin{tabular}{|c|c|c|c|c|c|}
\hline Site & $\underset{\mathrm{km}}{\text { Distance }^{(\mathrm{a})} \text {, }}$ & $\begin{array}{l}\text { Compass }(a) \\
\text { Direction }\end{array}$ & $\begin{array}{l}\text { Elevation } \\
\text { Above } \\
\text { MSL, m } \\
\end{array}$ & Surface Soil & Vegetation \\
\hline Study Area & 1 to 6 & $E$ to NNE & 120 to 200 & Ringold Sediments & Rabbitbrush, Sagebrush \\
\hline Riverview & 10 & SSE & 140 & Alluvial & Sagebrush \\
\hline Exxon & 3 & SW & 115 & Stabilized Dunes & Rabbitbrush, Sagebrush \\
\hline Prosser Barricade & 11 & W & 140 & Stabilized Dunes & Rabbitbrush, Sagebrush \\
\hline Yak ima Barricade & 43 & NW & 240 & Alluvial & Sagebrush \\
\hline Sunnyside & 53 & WSW & 450 & Loess & Rabbitbrush, Sagebrush \\
\hline
\end{tabular}

(a) Straight line distance and direction from the 300 Area. 
crowns of the hills. The bluffs were composed of ancient Ringold Formation sediments with partic le sizes ranging from clay to cobble rock. Surface soils consisted of fine-grained materials mixed with some small gravel. Vegetation was composed primarily of shrubs, perennial bunchgrasses and annuals.

The control site at Riverview was used because of its similarities to the study area. The site was located several kilometers inland from the eastern shore of the Columbia River, but topography, surface soil, and vegetation were similar to the study area. However, the geological formation was not Ringold Sediments, but rather outwash materials from historical Columbia River activity. The Prosser Barricade control site and the Exxon site were located in an area of stabilized sand dunes with gentle undulating topography. The Yakima Barricade control site was located in an area of Columbia River outwash lightly veneered with wind-blown materials. The Sunnyside control site was considerably higher in elevation (450-m MSL) than the study area and far removed in an upwind direction from the influence of operations at Hanford. The soil was derived from loess which overlies basalt. Vegetation at the control sites and the Exxon site was basically the same as the study area except at Sunnyside where large perennial bunchgrasses were prevalent. 
METHODS

Sampling and analytical methods were patterned after those used routinely in the Hanford Environmental Surveillance Program (Sula et al. 1982).

SAMPLING AND ANALYSIS

Each sample of surface soil was collected using a steel "cookie cutter" sampler. The size of the sampler was $10 \mathrm{~cm}$ in dia meter by $2.5 \mathrm{~cm}$ deep. Three different classes of soil samples were collected and analyzed:

- individual-a single soil sample;

- field composite-composed of five soil samples composited in the field by placing the samples as collected into a plastic bag;

- lab composite-composed of equal aliquots of "individual" samples composited in the laboratory after drying and sieving.

Samples from the same site for individual use or for compositing in the field were selected from areas of $\sim 100 \mathrm{~m}^{2}$. Lab composites were prepared after aliquots from the individual samples were separated and analyzed. Lab composite samples were submitted blind for analysis.

Soil samples were dried at $110^{\circ} \mathrm{C}$ and sieved to pass a 2-mm stainless steel screen. Aliquots of $10 \mathrm{~g}$ of soil were leached with acid and used for uranium analysis by the fluorometric method (UST 1980). Analysis for heavy metals was by the atomic absorption method and used 5-g aliquots (UST 1980).

Vegetation samples consisted of $\sim 100 \mathrm{~g}$ of recent growth cut from sagebrush or rabbitbrush shrubs. If the site had both types of shrubs represented, then the sample contained both in about the same proportion as their occurrence. Samples were dried at $60^{\circ} \mathrm{C}$ and ground. Aliquots for uranium and heavy metal analyses consisted of $5 \mathrm{~g}$ and $1 \mathrm{~g}$, respectively. Fluorometric and atomic absorption methods were used (UST 1980). 
STATISTICAL METHODS

The purpose of the study was to evaluate the potential impact of operations at the 300 Area on the study area using the control sites for comparison. Statistically this purpose translates into an exploratory data analysis thus, the primary data analys is tools used were graphical methods.

The data for all elements were examined for statistical distributions using probability plots and the correlation coefficient goodness of $f$ it test (Filliben 1975). These analyses showed that only the uranium and copper data might reasonably be expected to show effects, thus only these two elements were further analyzed. The further analyses consisted of 1) an analysis of variance test for spatial pattern within the study area, 2) an analysis of variance test for differences between the study area and control sites, 3) an analysis of variance comparison of sample types for uranium, 4) a graphical and analysis of variance test for consistency of uranium laboratory propagated errors, 5) an analysis of variance test of the consistency of the quality control data, and 6) a graphical analysis of uranium to copper ratios.

\section{SAMPLING DESIGN}

Table 2 lists the numbers of samples analyzed for each sample type. The "individual" soil samples from study area sites at locations 0.8 through $4.8 \mathrm{~km}$, and from the Riverview control site were collected and analyzed in the fall of 1981 as a preliminary study. Samples were analyzed for uranium silver, beryllium, cadmium, chromium (total), copper, mercury, nickel, lead, and zinc. The choice of heavy metal analyses was based on materials known to have been used in the 300 Area over the years. A review of the results indicated that additional soil samples and some vegetation samples should be collected and analyzed for lead, silver, zinc, copper, and uranium. The other heavy metals were low in concentration and further analyses would not have been productive. Additional control sampling sites were established to improve comparisons. 
TABLE 2. Soil and Vegetation Samples Collected at Each Sampling Site

\begin{tabular}{|c|c|c|c|c|c|c|}
\hline Sampling Sites & \multirow[b]{2}{*}{$0.0(a)$} & \multirow[b]{2}{*}{$\begin{array}{l}0(0) \\
40 \\
80\end{array}$} & \multicolumn{2}{|c|}{ Number of Soil Samples by Sample Type } & $\frac{\text { Type }}{\text { Lab }}$ & $\begin{array}{r}\text { Number of } \\
\text { Veget at ion } \\
\text { Samples } \\
\end{array}$ \\
\hline Study Area & & & & $\begin{array}{l}5 \\
5 \\
5\end{array}$ & & 5 \\
\hline & 0.8 & $\begin{array}{r}0 \\
40 \\
80\end{array}$ & $\therefore 5(+5$ reanalyses $)$ & $\begin{array}{l}1 \\
5 \\
5\end{array}$ & 4 & 5 \\
\hline & 1.6 & $\begin{array}{r}0 \\
40 \\
80\end{array}$ & 5 & $\begin{array}{l}5 \\
5 \\
5\end{array}$ & 4 & 2 \\
\hline & 2.4 & $\begin{array}{r}0 \\
40 \\
80\end{array}$ & 5 (+ 5 reanalyses) & $\begin{array}{l}1 \\
5 \\
5\end{array}$ & 4 & 2 \\
\hline & 3.2 & $\begin{array}{r}0 \\
40 \\
80\end{array}$ & 5 & $\begin{array}{l}1 \\
5 \\
5\end{array}$ & 4 & 5 \\
\hline & 4.0 & $\begin{array}{r}0 \\
40 \\
80\end{array}$ & $5(+5$ reanalyses $)$ & $\begin{array}{l}1 \\
5 \\
5\end{array}$ & 4 & 5 \\
\hline & 4.8 & $\begin{array}{r}0 \\
40 \\
80\end{array}$ & 5 & $\begin{array}{l}1 \\
5 \\
5\end{array}$ & 4 & 2 \\
\hline & 5.6 & $\begin{array}{r}0 \\
40\end{array}$ & & $\begin{array}{l}5 \\
5\end{array}$ & & 2 \\
\hline Riverview & & & $5(+5$ reanalyses $)$ & 5 & 4 & 2 \\
\hline Exxon & & & & 10 & & 2 \\
\hline Prosser & & & & 5 & & 2 \\
\hline Yak ima & & & & 5 & & 2 \\
\hline Sunnyside & & & & 10 & & 5 \\
\hline
\end{tabular}

(a) Specif ic locations measured horizontally in kilometers from the northern-most sampling site at the study area.

(b) Specif ic locations measured vertically in meters above the rodd at the study area.

The "field composite" soil samples were collected and analyzed in the spring of 1982. New data-reporting techniques were developed by the analytical laboratory and a propagated error was calculated for each uranium result (see Appendix $A$ for methodology). As a means of establishing a cross check between the two periods of laboratory analyses (Fal1 1981 and Spring 1982), individual samples from study area sites $0.8,2.4,4.0 \mathrm{~km}$ and the Riverview control site were submitted blind to the laboratory for reanalys is including the computation of propagated errors. 
"Lab composite" samples were prepared by compositing individual samples by location and submitting blind duplicate samples twice for analysis. The results from these analyses were used to check on analytical result reproducibility and the relationship between individual samples and their composite.

The numbers of vegetation samples to be collected from each site were determined after all soil results were reviewed. Based on the soil data, vegetation sample results from the study area were not expected to show differences in heavy metal concentrations when compared to the control sites. If differences existed, they were expected to occur at study area sites 0.0, 0.8, 3.2 and $4.0 \mathrm{~km}$ where five vegetation samples were collected as noted in Table 2. Duplicate samples were collected at the remaining study area sites and at the control sites except Sunnyside where 5 samples were collected.

DATA ANALYSIS

Soil and vegetation samples from various locations in the Hanford environs have been analyzed for uranium content since 1973 providing a data base totaling more than 400 results. The following relationships were examined to compare the historical data base with the results from this study.

- Results from the study area and control sites was compared to the data base using the log-probability plotting technique.

- The mean value of uranium in soil at the study area was compared to the mean value at the control sites. A test of the difference of the means plus $0.7 \mathrm{pCi} / \mathrm{g}$ was considered significant.

The adequacy of the current soil sampling method used in the routine surveillance program also was evaluated.

- A fluctuation in uranium concentration results of greater than $\pm 50 \%$ (defined as the half-range divided by the mean) at any site where five or more composite samples were collected would result in an evaluation of the current soil sampling procedure. 
Analytical precision for uranium analyses was evaluated by comparing the analytical propagated error with the results of duplicate and replicate analyses.

- Differences in uranium results between duplicate and replicate analyses which significantly exceed the analytical propagated errors would result in the evaluation of the current analytical procedure. 


\section{RESULTS AND DISCUSSION}

Data for lead, silver, and zinc analyses were of limited use in evaluating possible effects on soil and vegetation from operations in the 300 Area. Only a brief description of these results will be presented followed by a more detailed descriptions of copper and uranium results. Soil analyses will be discussed first followed by a review of vegetation results. Results for soil or vegetation samples from the Exxon site were determined to be no different than the control sites. Hence, the general term "control sites" used in the following data analyses includes the Exxon site data.

\section{SOIL SAMPLES}

$\underline{\text { Lead }}$

Probability plots of all lead data did not fit either a normal or lognormal distribution. One sample result (from the study area) was an obvious outlier; however, removal of this single point did not significantly increase the goodness of $f$ it to either the normal or lognormal distribution. The lead data were then separated into subsets for the study area and for the control sites. The data for the control sites fit both a normal and a lognormal statistical distribution; however, the fit to the normal was much better than the $f$ it to the lognormal. The subset of lead data for the study area $f$ it neither distribution and appeared to be a mixture of at least three different distributions. The mixed distributions were not analyzed further. Average soil concentrations for lead are given in Table 3 . There was no apparent difference in lead content of soils between the study area and the control sites.

Silver

The silver data reasonably fit both normal and lognormal statistical distributions, but the fit to the normal was better than to the lognormal. Because the range of values of this data set was small (25 to $90 \mathrm{ppm}$ ), the data could fit many distribution models. A significant statistical problem with the silver data was that most of the values (96\%) had one of eight discrete values: $0.30,0.35,0.40,0.45,0.50,0.55,0.60$, or $0.65 \mathrm{ppm}$. Because of this and 


\section{TABLE 3. Mean, Standard Deviation (SD), and Range of Heavy Metal Analyses}

of Soil Samples (ppm dry wt)

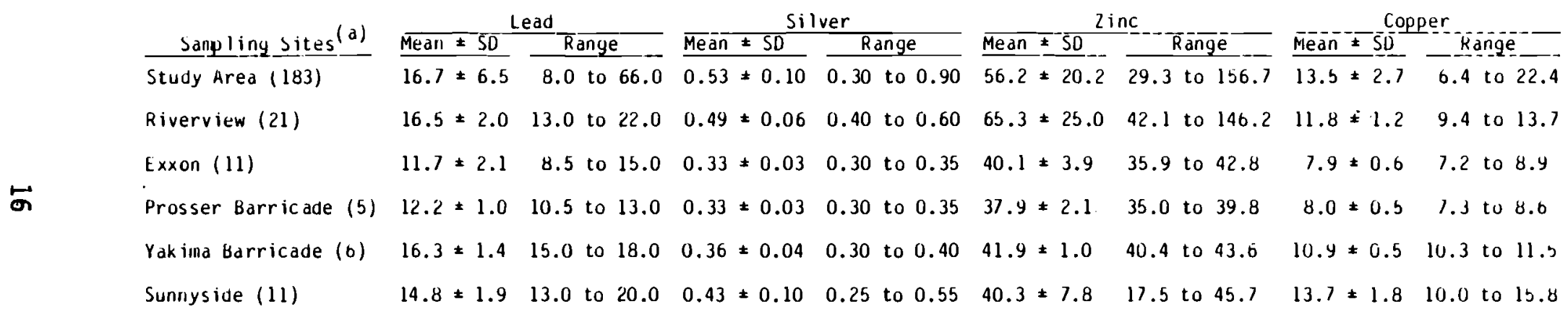

(a) The number in parenthesis is number of samples analyzed including replicates and quality control duplicates. 
because all silver concentrations were extremely low, no further analysis of the silver data was done. Average soil concentrations for silver are given in Table 3. No difference between the study area and the control sites was evident using robust statistical comparisons.

$\underline{\text { Zinc }}$

The zinc data also fit neither normal nor lognormal distributions. The study area data subset appeared to be a mixture of distributions. The subset of control sites data appeared to be a mixture of two distributions where all areas except Riverview fell into one distribution. The Riverview data had both a larger mean and a larger standard deviation than the other control sites. There may also have been two outliers in the Riverview data, but the removal of these two data values would not alter the observed pattern in the data. Again, statistical tests could not be performed on the mixed distributions and no further analysis of the zinc data was done. Average soil concentrations for zinc are given in Table 3. No difference between the study area and the control sites was noted.

Copper

A probability plot correlation coefficient test showed that the copper data for the study area could follow either normal or lognormal statistical distributions. However, the $f$ it to the norma 1 was much better than to the lognormal, thus the assumption of a normal distribution was used for statistical testing. The probability plots revealed four possible outliers at the high end. These four samples were collected from the study area at the base of the bluff (0-m vertical) and at 0.8-km horizontal. The range of values for these four samples was from 19.9 to $22.4 \mathrm{ppm}$. Other sample types analyzed from this same location ranged in value from 14 to $18 \mathrm{ppm}$, so the suspected outliers were not greatly different from nonsuspect samples. All samples were then included in the data analyses.

The copper values for the control sites did not pass the probability plot correlation coefficient test for $f$ it to a lognormal distribution and just barely passed the test for the normal distribution. An examination of the probability plot did not reveal any special features such as clustering of 
values or mixtures of distributions. A normal distribution was assumed for the purpose of comparison to the study area. Field composite samples were used in a one-way analysis of variance test for comparing the control sites with the study area. The test found a highly significant difference between means of locations. Linear contrasts were then used to find how loc ation means were statistically grouped. This procedure resulted in two overlapping groups of means. Exxon, Prosser Barricade, Riverview and Yakima Barricade means formed one group, and Riverview, Yakima Barricade, the study area and Sunnyside means formed a second group. The relationships were:

\begin{tabular}{|c|c|}
\hline Location & $\begin{array}{l}\text { Mean Copper } \\
\text { Value (ppm) }\end{array}$ \\
\hline Exxon & {$[7.97$} \\
\hline Prosser Barricade & 8.00 \\
\hline Riverview & 10.247 \\
\hline Yak ima Barricade & L10.94 \\
\hline Study Area & 12.38 \\
\hline Sunnys ide & 13.20 \\
\hline
\end{tabular}

Replicate analyses of samples and several types of sampling data were available for sampling locations at the base of the bluff in the study area. Except for location $1.6 \mathrm{~km}$, no significant differences were found between the mean values for copper in individual samples, replicates of individual samples, field composites, or laboratory composites. At the 1.6-km loc ation the mean of individual samples was significantly different from the mean of laboratory composites, but neither of these means was significantly different from the field composite mean. The analysis of the copper quality-control data concluded that the quality-control duplicates were not statistically different from the record sample analyses. The correlation coefficient for all copper values and their quality control duplicates was 0.794 which is significantly greater than zero at the $99 \%$ confidence level. When the data were separated by sample type, the corresponding correlation for individual samples was 0.730 , which is significant at between 95 and $99 \%$, and the correlation for field composites was 0.945 . Although these correlations show that the quality-control duplicates were not statistically different from the corresponding record 
sample values only the field composite data show really good agreement. It was concluded that the precision in copper analysis was adequate in this study. Uranium

One of the relationships to be examined in the uranium data was a comparison of the data from this study with those of the historical data base. Figure 3 shows lognormal probability plots for the historical soil uranium data, as determined for the routine Hanford Environmental Surveillance Program, and for all sample types at the study area. The two sets of data obviously belong to two different populations. When the control-site data were included with

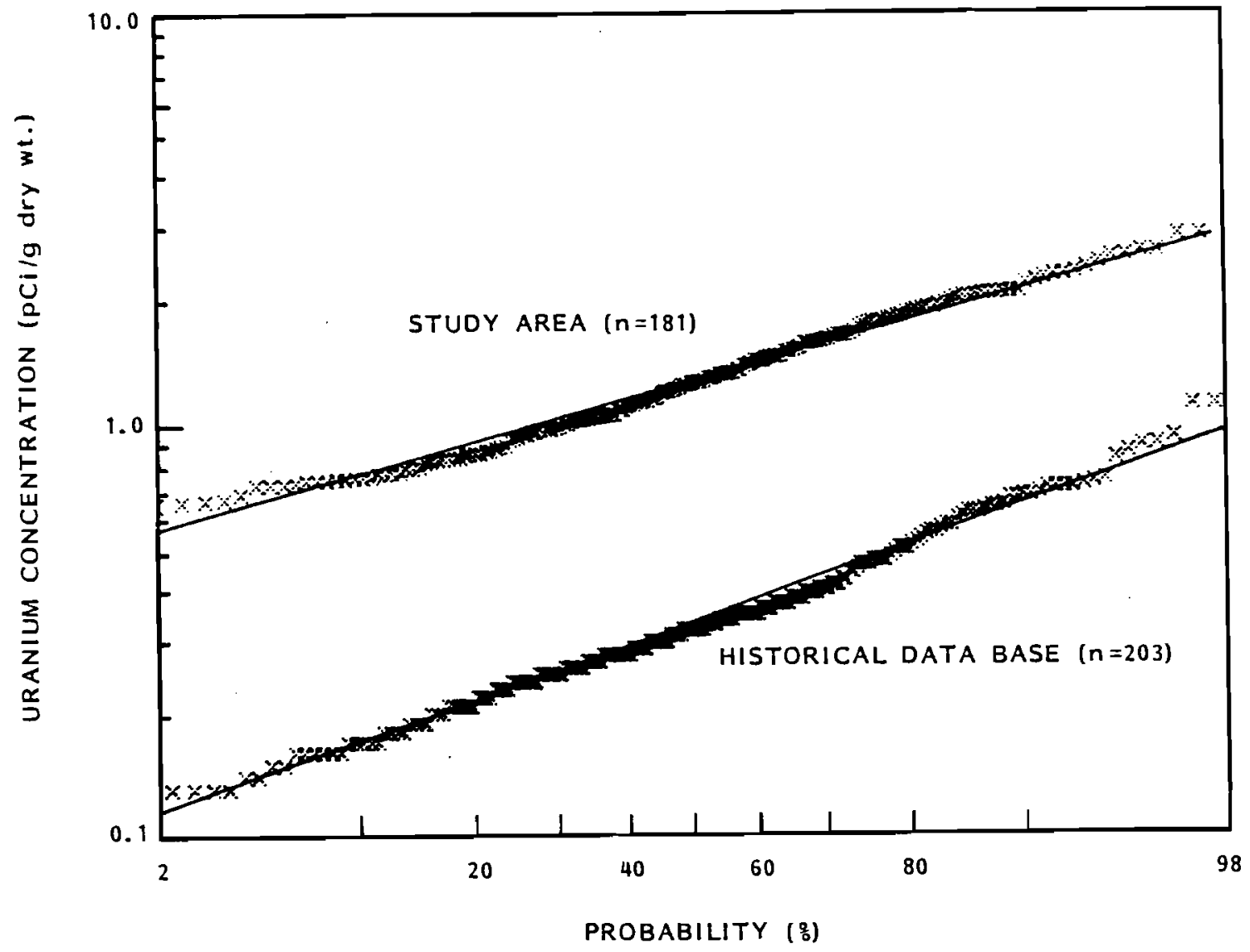

FIGURE 3. Probability Plots of Soil Uranium Concentrations for the Historical Data Base (1973-1981) and for the Study Area 
the historical data, the resulting lognormal probability plot was virtually the same as the historical data alone. Table 4 provides a comparison of the data from the historical data base, the study area, and the control sites for all types of soil samples. It again appears that two different populations are represented. When the average uranium concentrations given in Table 4 as $\mathrm{pCi} / \mathrm{g}$ are converted into $\mathrm{ppm}$ (historical $=0.5$; study area $=2.0$; control sites $=0.8)$, all values are within the range of the average uranium concentrations $(0.2$ to $10 \mathrm{ppm})$ in the majority or rocks and sediments making up the earth's crust (Seaborg 1973). For another comparison to historical data, the average uranium concentration for the study area was determined to be significantly greater than $1 \mathrm{pCi} / \mathrm{g}$. The difference was found to be at least 0.7 with essentially $100 \%$ conf idence.

Most of the data representing the study area were from field composite samples. All control site data, except Riverview, also were from field composites. These data were used statistically to compare uranium concentrations at the study area with those at the control sites (see Table 5). Both data sites fit a lognormal distribution better than a normal statistical distribution. A one-way analys is of variance was performed to compare the logarithms of the uranium concentrations of all field composite samples, and a very significant difference was found between sampling locations. The analys is of variance resulted in an F-value of 42.07 with 4 and 124 degrees of freedom. Comparing the mean values using linear contrast showed that the data fell into two distinct groups: the study area, and the control sites. There were no

TABLE 4. Uranium in Soil Samples from the Environs of the Hanford Site ( $p C i / g$ dry wt)

\begin{tabular}{|c|c|c|c|}
\hline Sample Source ${ }^{(a)}$ & Mean \pm SO & Median & Range \\
\hline Historical Data (203) & $0.38 \pm 0.23$ & 0.32 & 0.1 to 1.4 \\
\hline Study Area (181) & $1.4 \pm 0.54$ & 1.2 & 0.51 to 3.1 \\
\hline Control Sites (55) & $0.51 \pm 0.15$ & 0.49 & 0.21 to 0.86 \\
\hline
\end{tabular}

(a) The number of sample results is given within parenthesis. 
TABLE 5. Statistical Data for Uranium Concentrations in Field Composite Samples Collected from the Study Area and Control Sites

\begin{tabular}{|c|c|c|c|c|}
\hline Sampling Sites (a) & Mean & $\begin{array}{l}\text { Natural Log } \\
\text { of Data } \\
\text { Mean } \pm \text { SD }\end{array}$ & Median & Range \\
\hline Study Area (95) & 1.34 & $0.22 \pm 0.39$ & 1.23 & 0.63 to 3.13 \\
\hline Riverview (5) & 0.61 & $-0.50 \pm 0.21$ & 0.60 & 0.50 to 0.86 \\
\hline Exxon $(10)$ & 0.50 & $-0.70 \pm 0.26$ & 0.54 & 0.34 to 0.75 \\
\hline Prosser Barricade (5) & 0.37 & $-0.99 \pm 0.35$ & 0.44 & 0.21 to 0.48 \\
\hline Yakima Barricade (5) & 0.47 & $-0.76 \pm 0.12$ & 0.46 & 0.39 to 0.52 \\
\hline Sunnyside (10) & 0.37 & $-0.99 \pm 0.30$ & 0.38 & 0.26 to 0.60 \\
\hline A11 Control Sites (35) & 0.47 & $-0.81 \pm 0.31$ & 0.48 & 0.21 to 0.86 \\
\hline
\end{tabular}

(a) The number of sample results is given within parenthesis.

significant differences among the five control sites, and the study area had significantly higher uranium concentrations than the control sites combined.

The uranium data were also used to evaluate the current soil sampling procedure. The procedure was to be judged as unsatisfactory if a fluctuation in uranium concentration values of greater than $\pm 50 \%$ was found at any site where five or more composite samples were collected. A mathematical statement of this criterion is: 0.5 range/mean $\leq 0.5$ for any sampling site with $n \geq 5$. This criterion was applied to each of the sampling sites within the study area and to the control sites. In all cases the criterion was satisfied. The largest value for the half-range divided by mean was 0.45 , at the location $40-m$ vertical and 4.0-km horizontal in the study area. The smallest value, 0.13, was also located in the study area, at 40-m vertical and 5.6-km horizontal.

A one-way analysis of variance was used to test for spatial pattern within the study area. This method as sumes that if there were no spatial pattern, all sampling locations could be considered as independent samples from a single population. Spatial pattern can then be tested using linear contrast between the means of sampling locations. The spatial pattern test using uranium fieldcomposite data showed a highly significant difference between sampling locations. Thus, there is an apparent spatial pattern for uranium concentrations 
at the study area. Figure 4 shows a simple plot of sampling locations with uranium concentrations significantly greater than $1 \mathrm{pCi} / \mathrm{g}$ distinguished from locations with less than $1 \mathrm{pCi} / \mathrm{g}$.

Because individual samples were collected only at the zero elevation in the study area, the analysis of spatial pattern cannot be repeated for them. However, differences among the six locations for which individual uranium sample data are available $c$ an be examined. A one-way analys is of variance showed that the samples collected at $3.2 \mathrm{~km}$ had a mean concentration significantly higher than all other sampling locations and significantly greater than $1 \mathrm{pCi} / \mathrm{g}$ ( $1.9 \mathrm{pCi} / \mathrm{g}$ with a lower $95 \%$ confidence limit of $1.3 \mathrm{pCi} / \mathrm{g}$ ). Note that when field composite samples were used, this location yielded a uranium concentration significantly less than $1 \mathrm{pC} / \mathrm{g}$. Field composite samples also idenitified high concentrations at locations $2.4,4.0$ and $4.8 \mathrm{~km}$. The reason for largescale spatial variations was not determined. Even though statistical differences were noted, the actual differences in uranium concentrations were relatively small compared to background concentrations and probably represent natural variability at the site.

+ mean not significantly above $1 \mathrm{pCi} / \mathrm{g}$

0 mean significantly above $1 \mathrm{pCi} / \mathrm{g}$

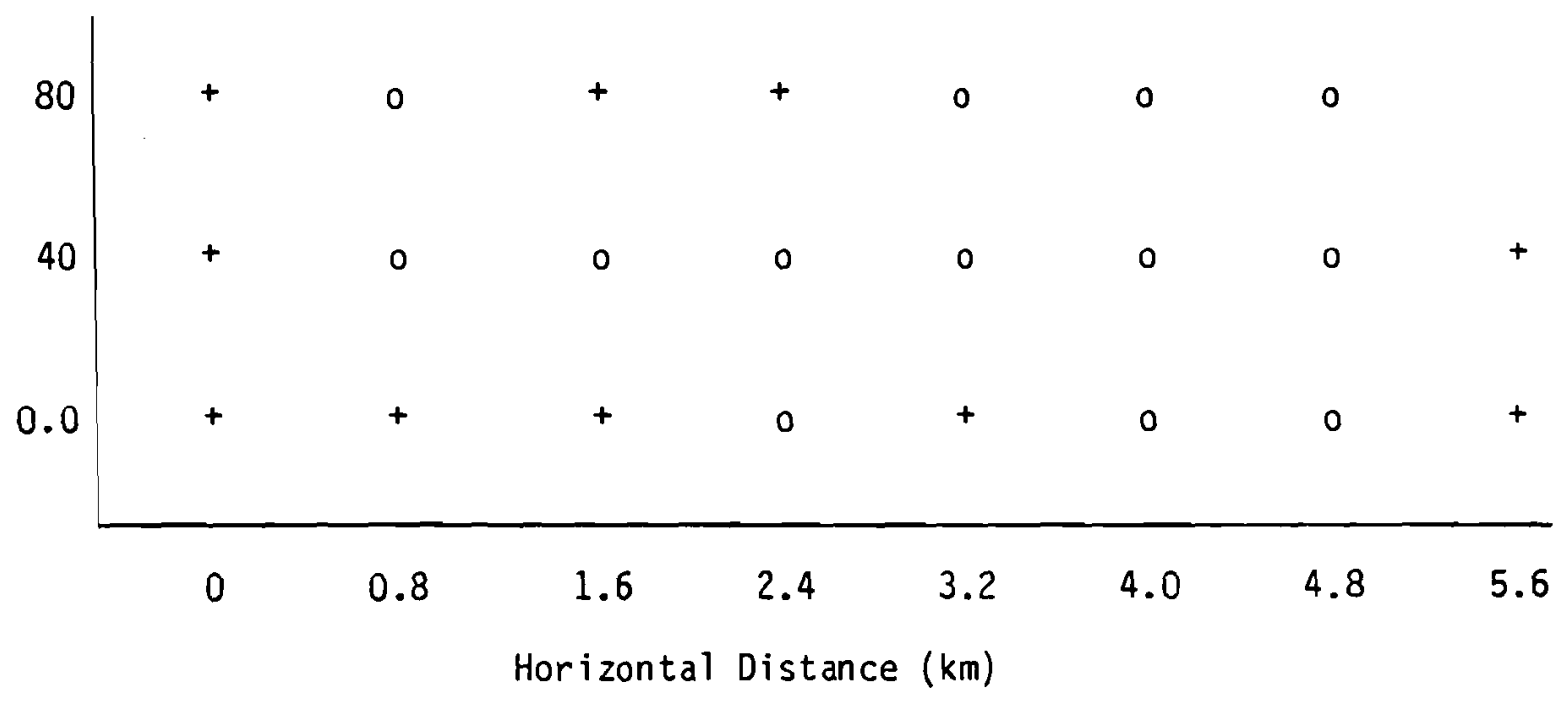

FIGURE 4. Graphic Representation of the Spatial Pattern of Uranium Concentrations in Field-Composite Samples Collected from the Study Area 


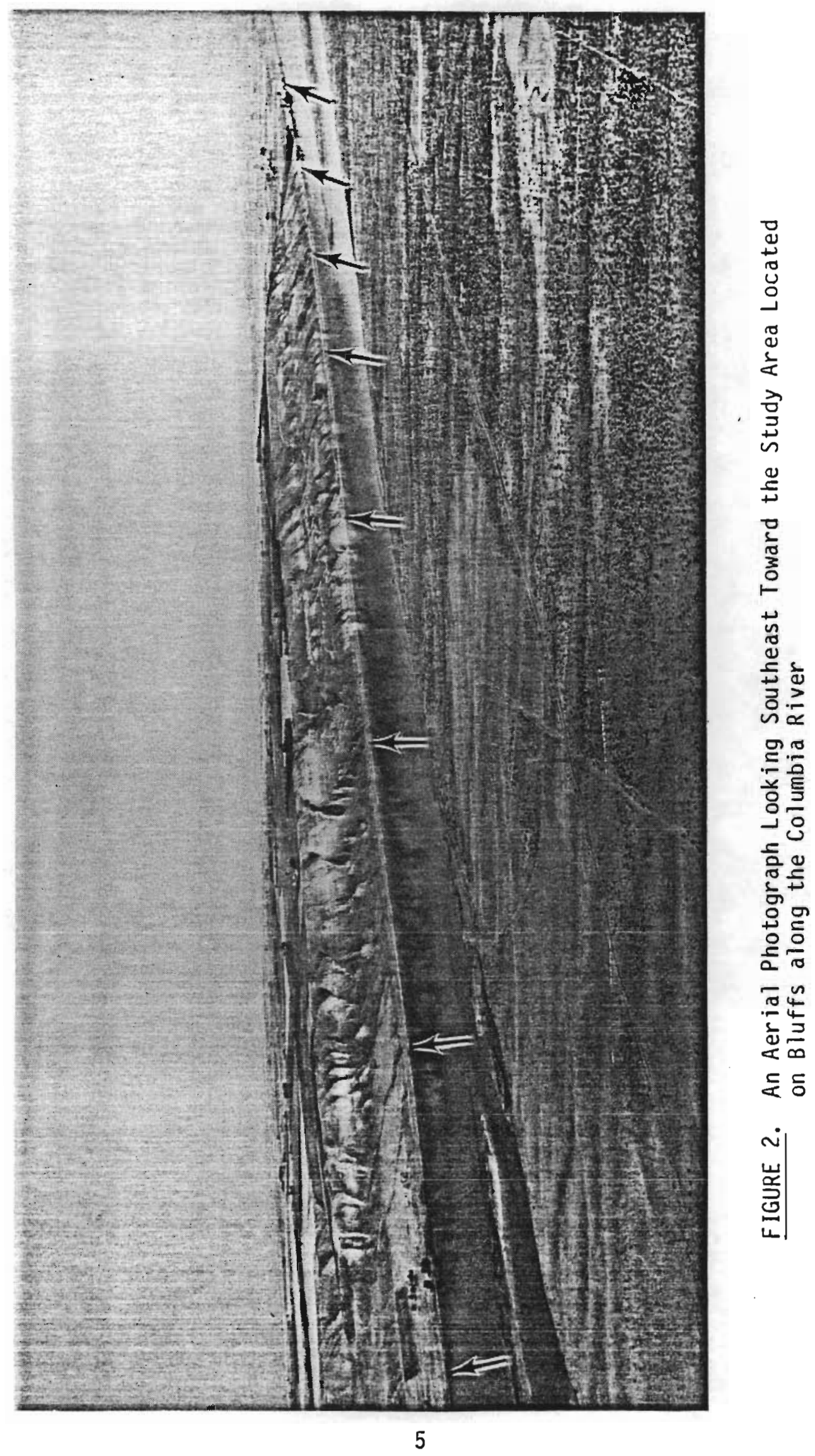


The residual mean square errors (from the test of spatial pattern) of field composite and individual samples were compared using an F-ratio. This is a test of significance for differences in variability between the two different sampling methods. The test gave an F-value of 3.00 with 39 and 72 degrees of freedom indicating that the individual samples were much more variable than field composite samples. This suggests that a very small-scale spatial variability in uranium concentrations was averaged out by the process of field compositing.

Some replic ate uranium analyses were performed. In most instances where replicates were analyzed, there also were data on several sampling techniques for that sampling location. Thus a simultaneous comparison of sample type (individual samples, field composite, and laboratory composite) and sample replication could be done. Sometimes significant differences were noted between the means of different sample types. For example, at 2.4-km horizontal and $0-m$ vertical the laboratory composite mean was significantly lower than the field composite mean. Although the results varied from sampling location to sampling location, the overall conclusion is that replicate samples did not differ significantly from the corresponding original analyses.

The uranium data were then analyzed to see if the quality control duplicates were statistically equal to the original sample analysis. The correlation between the original 24 sample values and their quality control replicates was 0.42 , which was significantly different from zero at the $95 \%$ confidence level but not at the $99 \%$ level. Because the distribution of the uranium data was lognormal, the appropriate test was to determine if the difference in the logarithms was significantly different from zero. This test gave a Student's-t value of -1.14 with 22 degrees of freedom which corresponds to only a $75 \%$ level of confidence for the difference being greater than zero. Thus, by both the correlation test and the difference test one must statistically accept the hypothesis that the quality-control duplicates are similar to the corresponding original analyses. Quality-control duplicates are expected to be highly correlated and nearly identical, but in these data the relationship is just barely statistically significant. An examination of 
the cross plot of the uranium quality control data reveals an almost random scatter of the data values as shown in Figure 5. The apparent reason for the weak statistical agreement is that the quality control replicates do agree reasonably well with the original analys is value for concentrations of $<1 \mathrm{pCi} / \mathrm{g}$. However, there is very poor agreement for concentrations $>1 \mathrm{pC} / \mathrm{g}$.

The final analys is of the uranium data was an evaluation of the propagated analytical errors. Historically, the uncertainty for soil uranium analyses was assumed to be about 35\% of the uranium concentration and was based on reproducibility of fluorometer results. The laboratory was asked to determine the propagated error for the analyses to be performed in 1982 and to estimate

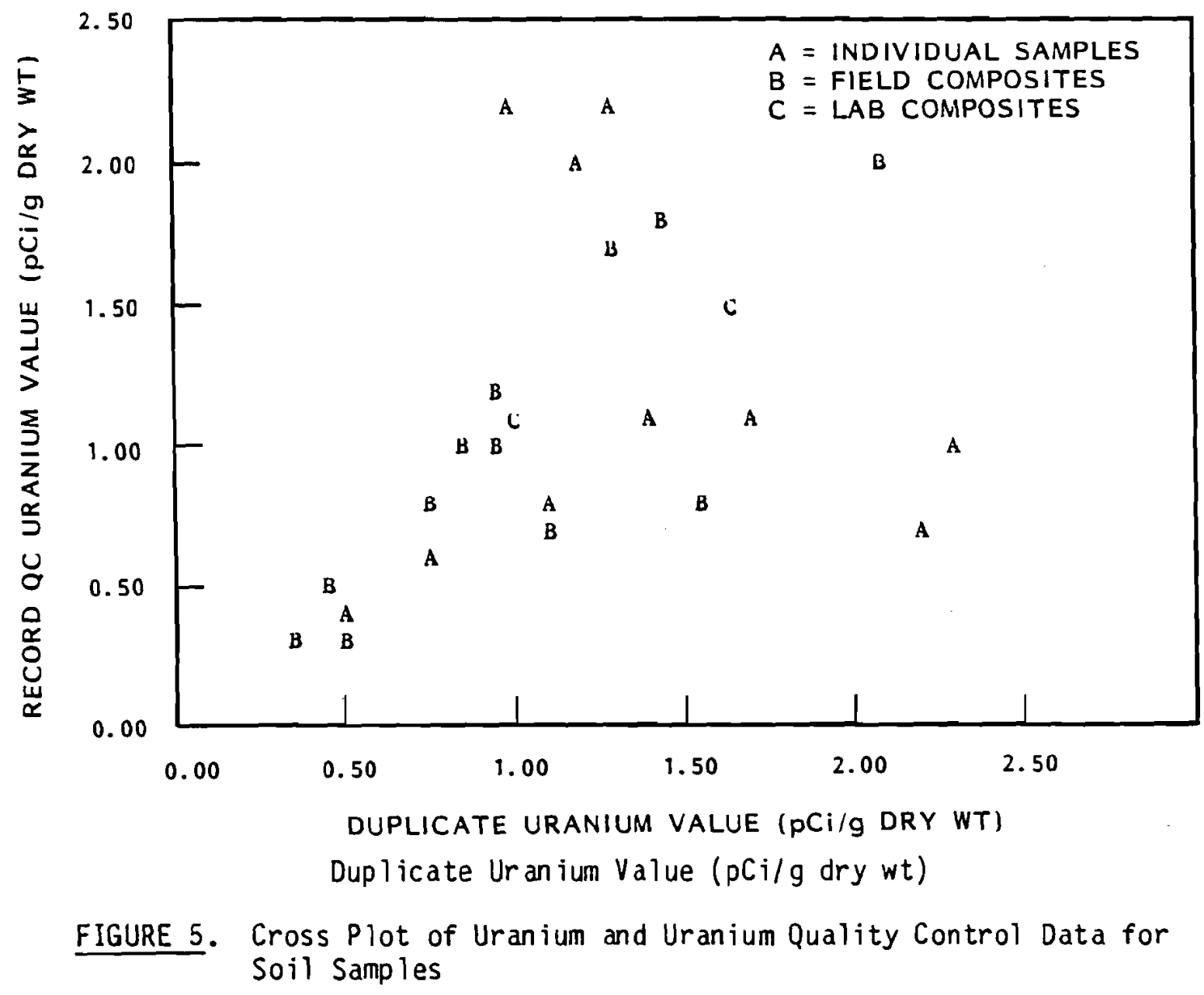


the propagated error for the analyses already completed in 1981. A scatter plot of uranium errors versus uranium concentration revealed two lines or relationships. The samples analyzed in September 1981 had significantly larger errors than the samples analyzed in February 1982 or March 1982. An analysis of variance showed that the ratios of analytic errors to corresponding uranium concentrations was significantly different for all three dates (i.e., February and March were also significantly different). Figure 6 is a plot of uranium concentration versus the percent error (ratio of propagated error to uranium concentration) and clearly shows these differences.

One of the relationships of interest identified at the beginning of this study was to compare the analytical propagated errors for uranium analyses with the errors associated with the replicates of field composite and lab composite samples. The comparison would show which type of error resulted in the best sensitivity for use in statistical hypothesis testing. The plots of percent error to uranium concentrations shown in Figure 6 demonstrate that the propagated errors were concentration dependent, hence, the variances were unequal. Common tests for differences between means, such as a Students-t test and the analysis of variance procedures, assume that the data from the groups being compared come from populations with normal distributions (or log transformations to normal distributions) and equal variances. Therefore, a statistical evaluation of the errors associated with the uranium analyses would be invalid. For this study then, the propagated analytical errors did not represent statistical errors associated with a sampling from the lognormal distribution of the transformed uranium concentration data and no comparisons of the error data could be made.

Ur an ium-Copper Ratios

Metalic copper was used as a lubricant during the extrusion process for the production of reactor fuel in the 300 Area. Waste copper solutions were disposed to the former 300-Area process waste ponds over the years in about the same proportion as uranium. The hypothesis that the former 300-Area process ponds could have been a potential source of wind-blown particles that settled on the bluffs across the river implies that the ratio of uranium to copper 


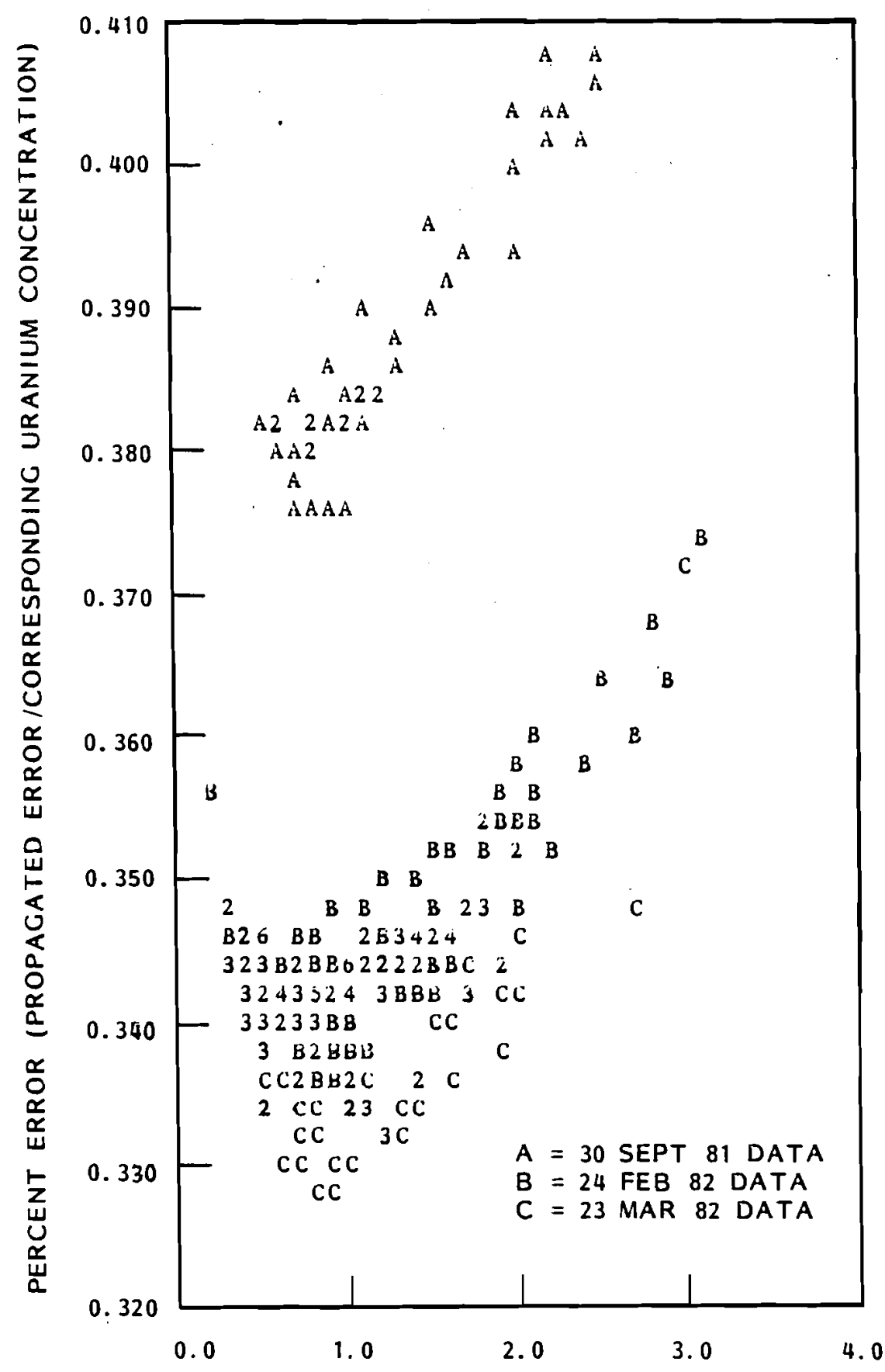

URANIUM CONCENTRATION ( $P C i / g$ DRY WT)

Uranium Concentration ( $p C i / g d r y w t$ )

Numbers on the plot count the number of data points that fall on the same point. 237 points are plotted.

FIGURE 6. Cross Plot of Uranium Concentration and the Ratio of Uranium Error to Ur an ium Concentration 
would be reasonably constant for the study-area samples but different for samples from the control sites provided no partitioning occurred during the transport process.

The uranium data, as noted previously, showed a lognormal distribution, whereas, the copper data fitted a normal distribution better than a lognormal one. While this difference may or may not be real, it does complicate the analys is of uranium-copper ratios because strictly speaking the logarithms of the uranium data should be compared to the actual copper data.

Scatter plots of the study-area data for both ur anium versus copper and the natural log of uranium versus copper indicated no relationships between the variables. The correlation coefficients for both sets of variables were $<0.3(n=183)$ which is a statistically significant difference from zero, however, the $95 \%$ confidence interval on the ratios was too wide to be of any practical value. For example, the $95 \%$ confidence interval on the ratio of the log of uranium to copper was -0.037 to +0.074. For a typical copper measurement of $15 \mathrm{ppm}$ the predicted uranium concentration would be, with $95 \%$ confidence, between 0.57 and $3.03 \mathrm{pCi} / \mathrm{g}$, a $6: 1$ range. The scatter plot of uranium and copper values for the control sites also indicated no relationship between uranium and copper measurements. The overall conclusion for ur aniumcopper ratios is that they are of no value to predict uranium levels from copper data.

Uranium I sotopes

Six samples from the study area and six samples from the Riverview control site were analyzed for uranium iotopic composition. Table 6 lists the average atom percent of ${ }^{234} \mathrm{U}, 235_{\mathrm{U}}$, and ${ }^{238} \mathrm{U}$ for each area. These values are essentially the same as those reported for naturally occurring uranium by

TABLE 6. Average Atom Percent of Uranium I sotopes in Soil Samples

\begin{tabular}{|c|c|c|c|}
\hline \multirow[b]{2}{*}{ Sampling Sites } & \multicolumn{3}{|c|}{ Mean $\pm S D(n=6)$} \\
\hline & ${ }^{234} U$ & ${ }^{235} \mathrm{U}$ & $238 \mathrm{U}$ \\
\hline Study Area & $0.0058 \pm 0.0005$ & $0.7233 \pm 0.0057$ & $99.2705 \pm 0.0059$ \\
\hline Control Site & $0.0054 \pm 0.0002$ & $0.7208 \pm 0.0030$ & $99.2737 \pm 0.0031$ \\
\hline
\end{tabular}


Seaborg $1973\left({ }^{234} U=0.006 \%,{ }^{235} U=0.71 \%\right.$, and $\left.{ }^{238} U=99.28 \%\right)$. There was no statistically significant difference between the study area data and the Riverview control-site data. If some of the uranium atoms in the study area soil samples were transported from the 300 Area, an enrichment in ${ }^{235_{U}}$ isotope would be expected because some of the reactor fuel prepared in the 300 Area was enriched with ${ }^{235} \mathrm{U}$. In fact, historical data on liquid effluents released to the former 300-Area process ponds in 1972 revealed a ${ }^{235} U$ content of 0.977 atom percent (ERDA 1975).

\section{VEGETATION SAMPLES}

Analytical results of uranium and other heavy metals in vegetation samples are summarized in Table 7. Probability plots revealed that many of the heavy metal data sets could fit either normal or lognormal distributions, whereas, the uranium fit only a lognormal distribution. Consequently, Table 7 lists the mean and its standard derivation, the median, and the range of values. There were no statistically significant differences between the study area and the control sites for any of the heavy metals and uranium in vegetation samples.

TABLE 7. Mean, Median and Range of Uranium ( $\mathrm{pCi} / \mathrm{g}$ ) and Heavy Metals (ppm) in Vegetation Samples

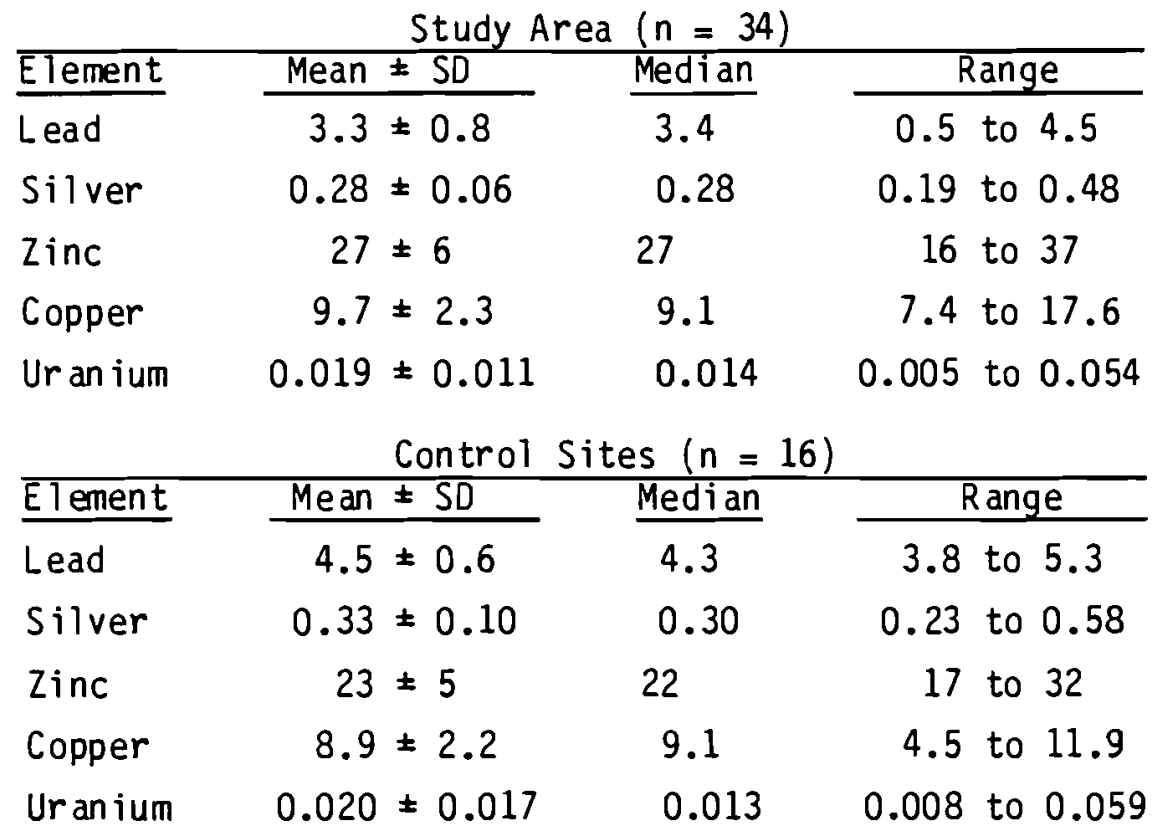




\section{CONCLUSIONS}

The purpose of this study was to estimate the concentrations of uranium and other heavy metals in soil and vegetation samples collected across the Columbia River from the 300 Area of the Hanford Site. Results were compared to those for control sites located both on and off the Hanford Site. These comparisons were used to evaluate the possibility that heavy metals had accumulated in the environs across the river from the 300 Area due to the transport of contaminated dust or other materials by strong winds.

The overall conclusion from this study is that operations at the 300 Area have not resulted in a detectable impact on the offsite environs across the river. This conclusion was based on the following:

- There was no significant difference between the study area and control sites in the concentrations of lead, silver, zinc or copper in soil or vegetation samples.

- There was no significant difference between the study area and control sites in the isotopic composition of uranium recovered from soil samples. Atom percent concentrations were virtually identical to those reported for naturally occurring uranium isotopes and were not enriched in ${ }^{235} \mathrm{U}$.

- There was no significant correlation between copper and uranium concentrations in soil samples from the study area or control sites even though approximately equal amounts were disposed to the former 300-Area process waste ponds.

Other findings and conclusions from the results of this study are:

- Soil uranium data showed lognormal distributions, whereas, lead, silver, zinc and copper data usually fit normal distributions or were mixed distributions.

- Soil and vegetation samples from the Exxon site were determined to be no different than the other control sites. 
- Lognormal probability plots of soil uranium data showed that the study area and control sites data were from different statistical populations.

- The mean soil uranium concentration for the study area was significantly larger than the mean of the control sites by more than $0.7 \mathrm{pCi} / \mathrm{g}$. (The $0.7 \mathrm{pCi} / \mathrm{g}$ was used to overcome the natural variation noted in other soil samples collected from the $H$ anford Site environs.)

- The variability in the soil sampling method (compositing) currently used for the Hanford Environmental Surveillance Program was determined to be less than $\pm 50 \%$ and superior to collecting individual samples.

- The analytical precision evaluated from duplicate and replicate analyses was acceptable for this study and is suitable for use in the Hanford Environmental Surveillance program.

- The propagated analytical error reported for soil ur anium analyses was unsuitable for statistical manipulations because the percent error was determined to be concentration dependent.

Soil samples from the study area represented a unique geologic formation (Ringold Formation) compared to the control sites used in this study. It is likely that the study area samples reflected a naturally-occurring anomaly and that some Ringold formation soils are slightly higher in uranium concentration than other local soils. 


\section{LITERATURE CITED}

ERDA. 1975. Final Environmental Statement, Was te Management Operations, Hanford Reservation, Richland, Wash ington. ERDA-1538, U.S. Energy Research and Development Administration, Washington D.C.

Filliben, J. J. 1975. "The Probability Plot Correlation Coefficient Test for Normality." Technametries, Vol. 17, 111-118.

Seaborg, G. T. 1973. "Uranium and Compounds." In the Encyclopedia of Chemistry, Third Edition, ed. C. A. Hompel and G. G. Hawley, pp. 1131-1133. Van Norstrand Reinhold Co., New York.

Sula, M. J., W. D. McCormack, R. L. Dirkes, K. R. Price and P. A. Eddy. 1982. Environmental Surveillance at Hanford for CY-1981. PNL-4211, Pacific Northwest Laboratory, Richland, Washington.

U.S. Testing Company, Inc. 1980. Procedure Manual. UST-RL-PM-9-80, U.S. Testing Company, Inc., Richland, Washington. 


\section{DISTR IBUTION}

No. of

Copies

OFFSITE

27 DOE Technical Information Center

\section{$\underline{\text { ONSITE }}$}

10 DOE RICHLAND OPERATIONS OFF ICE

R. E. Austin

R. E. Gerton

D. R. Elle (5)

H. E. Parson

H. E. Ransom

M. W. Tiernan

2 Rockwell Hanford Operations

R. M. Mitchell

D. L. Uh 1

3 Westinghouse Hanford Company
G. D. Carpenter
R. B. Hall
E. F. Yancey

No. of

Copies

2 UNC Nuc lear Industries, Inc.

L. P. Diediker

J. J. Dorian

E. A. Weakly

38 Pacific Northwest Laboratory

P. E. Bramson (2)

J. P. Corley

J. J. Fuquay

R. 0. Gilbert

R. R. Kinnison (5)

H. V. Larson

M. A. Mckinney

K. R. Price (15)

M. R. Quarders

W. H. Rickard

M. J. Sula

B. E. Vaughan

Publishing Coordination (2)

Technical Information (5) 